\title{
Accountability for environmental standards after Brexit
}

Maria Lee*

Professor of Law, Faculty of Laws, University College London, UK

Keywords

European Union, Brexit, United Kingdom, Government, Accountability

Nothing about leaving the European Union ("EU") is simple, and there is a growing and increasingly intricate literature on Brexit and the environment. ${ }^{1}$ The Government has promised that the Great Repeal Bill will bring 'the whole body of existing EU law', including environmental law, into UK law on the day we leave. ${ }^{2}$ No doubt there are important battles ahead over maintaining or improving environmental standards after that date. But as important, and as closely related to our forty-plus years of EU membership, is how effectively government is held to account for implementing these hard-fought environmental standards. We have been able to take for granted not only the big sticks of Commission-plus-Court of Justice enforcement mechanisms and fines, but also a more subtle architecture of transparency and political accountability, as well as a series of EU legal principles that render judicial review before domestic courts more effective. The aim of this opinion is to focus on these three, relatively simple, accountability mechanisms. Accountability is as complex as Brexit, with a huge literature behind it. But it can be simply described as a relationship between two parties in which one has an 'obligation to explain and justify conduct'; the actor being held to account is subject to some form of external scrutiny, as well as to the possibility of 'facing consequences'. ${ }^{3}$

\footnotetext{
* Professor of Law, Faculty of Laws, University College London, Bidborough House, 38-50 Bidborough St, Kings Cross, London, WC1H 9BT. E-mail: maria.lee@ucl.co.uk.

1 Blogs at http://environmenteuref.blogspot.co.uk/ (last accessed 11 May 2017) and https://academic.oup.com/jel (last accessed 11 May 2017) are a good place to start. The author has published a blog (one with Liz Fisher) on similar themes to the current opinion on each of those websites.

${ }^{2}$ Department for Exiting the European Union, Legislating for the United Kingdom's withdrawal from the European Union Cm 9446 (2017), para.1.12.

${ }^{3}$ M Bovens, 'Analysing and Assessing Accountability: A Conceptual Framework' (2007) 13 European Law Journal $447,450$.
} 
Bob Lee is right to warn against nostalgia for EU environmental law. ${ }^{4}$ And certainly no academic working in EU environmental law has ever thought that the EU is perfect, either in standard setting or in implementation. ${ }^{5}$ But nothing about the debate surrounding Brexit suggests the UK plans to move away from the dominance of economic growth and a marketorientated philosophy in its decision making on the environment, ${ }^{6}$ even if improvements are sought.

And there are things we shall miss. No doubt that includes the imposition of fines on government for the breach of environmental law. It seems unlikely that a mechanism for fining central government or government agencies will be introduced from scratch postBrexit, but it should not be dismissed out of hand. More importantly, the independent scrutiny provided by the Commission and Court is vital. And closely related to this scrutiny are the routine requirements in EU legislation that government plan the implementation of environmental obligations and report on progress. This enables political and legal, formal and informal, peer and citizen, scrutiny of government action. It is an important way to avoid the accountability challenges that arise because environmental compliance is often delayed, and never a box that can be ticked once and for all. Post-Brexit environmental governance must ensure that government bodies responsible for environmental protection explain, in a defined time frame, how they will meet their obligations; and report on progress, including on failure to comply, or on any lawful use of legal derogations, exceptions or 'alternative' standards, together with explanations of how compliance will be maintained or achieved. Reporting should be public, so that anyone can scrutinise and respond.

\footnotetext{
${ }^{4}$ R. Lee, 'Always Keep a Hold of Nurse: British Environmental Law and Exit from the European Union' (2017) 29 Journal of Environmental Law 155.

${ }^{5}$ The enforcement and accountability mechanisms being discussed here are far from perfect, see e.g. M. Hedemann-Robinson, Enforcement of European Union Environmental Law (Routledge: London, 2015).

${ }^{6}$ As acknowledged by Lee, above n. 4.
} 
All of this suggests that post-Brexit environmental governance requires a new body ${ }^{7}$ to scrutinise government plans, reports and activities. In addition to free standing powers of scrutiny, an obligation on this body to respond to government environmental plans and reports (a role currently performed by the Commission), completes that particular accountability loop. This body must have the expertise, independence and financial resources to provide meaningful scrutiny. Its minimum powers must be to expose government failure publicly, and require written responses from government to its own reports. It could have powers to impose sanctions, ambitiously including fines. But other sanctions, including formal declarations of failure, or requirements to put things right, are not without political and legal impact. Our new body could report to another body with sanctioning powers, referring government or government bodies to court, or to parliament, as is often the case with ombudsmen-type institutions.

Further, the Court of Justice realised decades ago that the 'the vigilance of individuals concerned to protect their rights' can be a central part of any supervision process. ${ }^{8}$ The doctrines of direct effect and consistent interpretation are an important part of that. Binding EU rules on access to justice, embedded in certain environmental directives, are also important in rendering access to courts meaningful. Equally important, although less noted, is the long-standing principle that national courts must provide adequate and effective remedies, which has been enormously important in the ClientEarth air quality litigation. ${ }^{9}$ It is not easy to recommend a way forward in this respect. Courts may develop common law remedial rights; statute could introduce a right to an effective remedy (or take it away). But the independent, expert, adequately resourced body referred to in the previous paragraph

\footnotetext{
${ }^{7}$ Or four bodies - here devolution is not being discussed here, but it is important to note that decision making on environmental protection must be sensitive to the debate on the UK's constitutional settlement. We 'take back control' from the EU, but who is 'we' in the context of environmental law? See C.T. Reid, 'Taking back control from Brussels - but where to?', https://blog.oup.com/2016/11/brexit-uk-eu-brussels/ (last accessed 11 May 2017).

${ }^{8}$ Case 26/62 Van Gend en Loos [1963] ECR 1, 13.

${ }^{9} \mathrm{R}$ (on the application of ClientEarth) v Secretary of State for the Environment, Food and Rural Affairs [2015] UKSC 28.
} 
should be open to complaints from members of the public. Moreover, as we saw in ClientEarth, a binding governance framework of planning and reporting can give a court something to get its teeth into in remedial terms.

The governance issues created by Brexit are on the agenda. Keir Starmer, Shadow Brexit Minister, is reported to have said in a speech that Labour would ensure the enforcement of environmental law post-Brexit, and perhaps he has some of the above in mind. ${ }^{10}$ Caroline Lucas, Green Party MP and co-leader, ${ }^{11}$ has issued a more detailed report calling for adequate environmental governance and accountability mechanisms. ${ }^{12}$ And environmental groups are of course working hard on this. ${ }^{13}$ The House of Lords EU Energy and Environment Sub-Committee, in its report on Brexit, found that the evidence it had heard 'strongly suggests that an effective and independent domestic enforcement mechanism will be necessary...underpinned by effective judicial oversight'. ${ }^{14}$ But the Government response is dismayingly dismissive, stating that the existing mechanisms of judicial review and parliamentary scrutiny are adequate. ${ }^{15}$ This is unlikely to have assuaged the SubCommittee's concern that 'The Government's assurances that future Governments will, in effect, be able to regulate themselves, along with Ministers' apparent confusion between political accountability to Parliament and judicial oversight, are worryingly complacent'. ${ }^{16}$

\footnotetext{
${ }^{10}$ ENDS Report, 'Labour Pledges Post-Brexit Environmental Enforcement' 25 April 2017.

${ }^{11}$ At the time of writing, Parliament has been dissolved for the forthcoming general election. There are formally no MPs during this period.

${ }_{12}$ C. Lucas, Exiting the EU, Not the Environment (2017), https://www.carolinelucas.com/sites/carolinelucas.com/files/Safe\%20Guarding\%20Environment\%20af ter\%20Brexit.pdf (last accessed 11 May 2017).

${ }_{14}^{13}$ E.g. http://greeneruk.org/index.php (last accessed 11 May 2017)..

14 Brexit: Environment and Climate Change, 12th Report of Session 2016-17 HL Paper 109. Recommendation 12, para 84. Also available at https://www.publications.parliament.uk/pa/ld201617/ldselect//deucom/109/109.pdf (last accessed 11 May 2017).

${ }^{15}$ Letter from Dr Therese Coffey MP, dated 16 April 2017, http://www.parliament.uk/documents/lordscommittees/eu-energy-environment-subcommittee/Brexit-environment-climate-change/Gov-responseBrexit-env-climate.pdf (last accessed 11 May 2017).

${ }^{16}$ Above n. 14, Recommendation 11, para83.
} 
There are also worrying statements in the White Paper on the Great Repeal Bill. As well as saving all EU law on Brexit, the White Paper proposes the use of delegated legislation to allow law to continue to operate once we are no longer members of the EU. The use of delegated legislation is probably inevitable, and will often be uncontroversial, avoiding impasse when we do not have access to certain EU institutions and processes. But two examples given by the White Paper highlight the risk that the political significance of important governance mechanisms may be overlooked. The White Paper refers to the Habitats Directive, ${ }^{17}$ specifically the obligation to obtain an opinion from the European Commission 'on particular projects relating to offshore oil and gas activities', presumably a deliberately obscure-sounding issue. ${ }^{18}$ The White Paper states that 'the power to correct the law would allow the Government to amend our domestic legislation to either replace the reference to the Commission with a UK body or remove this requirement completely'. ${ }^{19}$ Seeking an opinion from the Commission is a layer of safeguarding when a proposed development is particularly problematic for nature conservation. It is encouraging that the Government foresees the possibility of replacing the Commission in this context with a UK body. But whether to do so or not, and if so what that replacement body should be, is not a simple technical correction. It is a fundamental part of the governance structure, and should not disappear without debate.

Another example for the role of delegated legislation in the White Paper is about 'information sharing with EU institutions', and the proposal is that delegated legislation would allow Government to amend or repeal obligations to send information to the EU institutions. ${ }^{20}$ Again, an obscure piece of law is chosen, on the transport of goods by inland waterways. But in environmental law, information creation, collection and publication is a crucial aspect

\footnotetext{
${ }^{17}$ Directive 92/43/EEC (OJ L 206/7 22.7.92) on the conservation of natural habitats and of wild fauna and flora [1992]. Specifically, the Offshore Petroleum Activities (Conservation of Habitats) Regulations 2001 (SI 2001, No.1754)..

${ }_{18}$ Above n. 2, 20.

${ }^{19}$ Above n. 2, 20.

${ }^{20}$ Above n. 2, 21.
} 
of transparency and accountability. It may no longer make sense to send that information to the EU institutions (who presumably will no longer be carrying out their scrutiny function in any event). But deciding what to do about information creation and publication is, again, not a small technical question, but something that deserves the closest of attention.

Quite what Brexit means is of course a moving target, complicated even further at the time of writing by an imminent general election. There are many possible institutional variations to our future relationship with the EU. We have been promised a 'hard' Brexit - no membership of the internal market, no free movement of people, and no role for the Court of Justice; and so (presumably) no EU role in UK environmental protection. But we have also been promised a 'bold and ambitious free trade agreement that allows the freest possible trade in goods and services with the EU'. ${ }^{21}$ In this case, presumably the application of at least some EU environmental standards would be insisted upon by the EU (although the UK would have no status in setting the standards). These two positions are difficult to reconcile, but for our purposes, reconciliation is not necessary. Even the very softest of Brexits would leave some environmental standards and some environmental governance mechanisms beyond the reach of EU environmental law. The issues raised here need to be scrutinised whatever the outcome.

Brexit is absorbing enormous emotional and intellectual resources, from NGOs, government, academics and practitioners. Finding the energy to devote to the governance framework for accountability is not easy. But the EU has set the rules of engagement throughout the development of much modern environmental law. The architecture of government's legal and political accountability for the environmental standards to which it has committed itself (sometimes with great fanfare and self-congratulation) needs constant attention and is something that will no doubt initiate further debate.

${ }^{21}$ Above n. 15. 